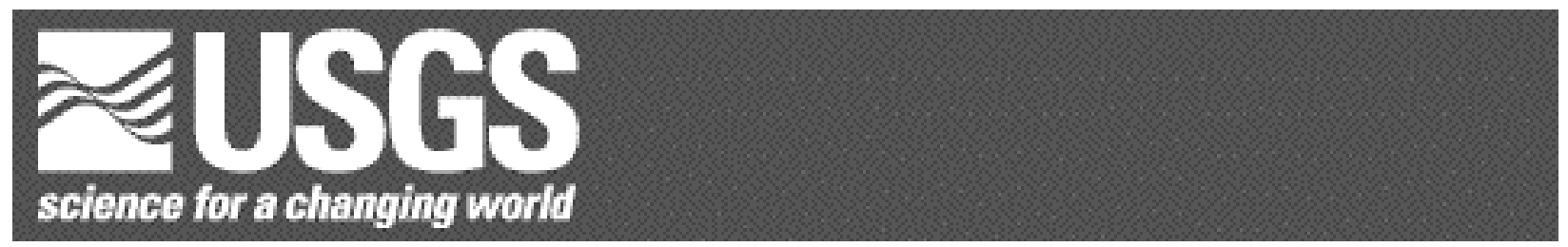

\title{
Cascadia Tsunami Deposit Database
}

By Robert Peters, ${ }^{1}$ Bruce Jaffe, ${ }^{1}$ Guy Gelfenbaum, ${ }^{2}$ and Curt Peterson 3

Open-File Report 03-13

2003

This report is preliminary and has not been reviewed for conformity with U.S. Geological Survey editorial standards or with the North American Stratigraphic Code. Any use of trade, firm, or product names is for descriptive purposes only and does not imply endorsement by the U.S. Government.

U.S. DEPARTMENT OF THE INTERIOR

U.S. GEOLOGICAL SURVEY

${ }^{1}$ U.S. Geological Survey, Pacific Science Center, 1156 High Street, Santa Cruz CA 95064

${ }^{2}$ U.S Geological Survey, 345 Middlefield Rd., Menlo Park CA 94025

${ }^{3}$ Department of Geology, Portland State University, Portland OR 97207 


\section{Contents}

Abstract............................................................................. 3

Introduction.............................................................. 3

Identification of CSZ Tsunami Deposits......................................4

Scope of the database........................................................

Limitations of database........................................................ 6

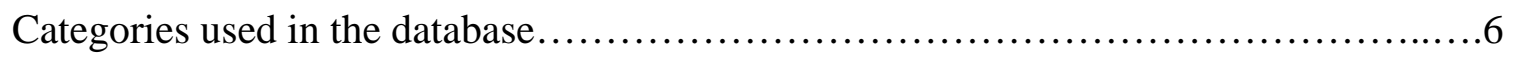

Acknowledgements......................................................... 13

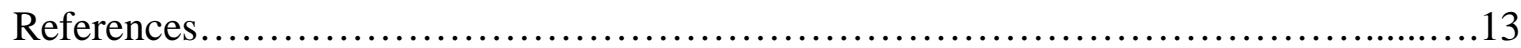

\section{List of Illustrations}

Figure 1. Map illustrating Cascadia margin tectonics..............................21

Figure 2: Map showing locations of tsunami deposits...........................22

\section{List of Tables}

Table 1. Name, Number, and references for sites in database $. . \ldots \ldots \ldots \ldots \ldots \ldots \ldots \ldots . . .23$ 


\begin{abstract}
The Cascadia Tsunami Deposit Database contains data on the location and sedimentological properties of tsunami deposits found along the Cascadia margin. Data have been compiled from 52 studies, documenting 59 sites from northern California to Vancouver Island, British Columbia that contain known or potential tsunami deposits. Bibliographical references are provided for all sites included in the database. Cascadia tsunami deposits are usually seen as anomalous sand layers in coastal marsh or lake sediments. The studies cited in the database use numerous criteria based on sedimentary characteristics to distinguish tsunami deposits from sand layers deposited by other processes, such as river flooding and storm surges. Several studies cited in the database contain evidence for more than one tsunami at a site. Data categories include age, thickness, layering, grainsize, and other sedimentological characteristics of Cascadia tsunami deposits. The database documents the variability observed in tsunami deposits found along the Cascadia margin.
\end{abstract}

\title{
Introduction
}

The Cascadia Tsunami Deposit Database is a compilation of published data on the location and sedimentary characteristics of tsunami deposits found along the Cascadia margin. It consolidates data from the earliest published reports on Cascadia tsunami deposits (e.g. Atwater, 1987, Reinhart and Bourgeois, 1987) to studies published or in press by the year 2002. This database and associated report is intended as a guide to the sedimentary features that characterize Cascadia tsunami deposits and to the locations where tsunami deposits have been found along the Cascadia margin. It also provides references for all of the tsunami deposits cited.

The Cascadia Subduction Zone (CSZ) is situated off of the Pacific Northwest coast of North America, from Northern California to Vancouver Island, British Columbia (Figure 1). Great earthquakes $(\mathrm{m}>8.0)$ on subduction zones have the potential to trigger large tsunamis. While not all subduction zones generate great earthquakes, it is believed that the CSZ has the potential to generate great earthquakes. The CSZ shares many features with other subduction zones that experience great earthquakes (Heaton and Kanamori, 1984). Geologic evidence for great earthquakes along the CSZ include turbidites off the Cascadia margin (Adams, 1990) and stratigraphic evidence of sudden coastal subsidence (e.g. Atwater et al., 1995, Nelson and Peronius, 1996). Although no great earthquakes have occurred on the CSZ since European colonization of the Pacific Northwest in the mid 1800s, an Indian oral tradition from the Pacific Northwest predating written records alludes to great shaking of the earth and coastal flooding (Heaton and Snavely, 1985, Clague, 1995).

Geologic evidence for large tsunamis along the Cascadia margin has only recently been recognized. Atwater (1987) published a report attributing anomalous sand layers in marsh sediments from southern coastal Washington to tsunamis generated by great earthquakes on the CSZ. Since this time, more than 50 studies have been published, documenting numerous sites containing confirmed or potential tsunami deposits and detailing deposit characteristics along the 
Pacific Northwest coast from Northern California to Vancouver Island, British Columbia (Figure 2). This rapid increase in our knowledge of Cascadia tsunami deposits has led to a greater public awareness of tsunami hazards, and improved our ability to assess the risk from future tsunamis. Data from tsunami deposits have been included on tsunami inundation maps (e.g. Walsh et al., 2000). Tsunami deposits are a key component to the recognition and mitigation of tsunami hazards in the Pacific Northwest.

\section{Identification of CSZ Tsunami Deposits}

The studies cited in the database use a variety of sedimentary features to identify tsunami deposits in outcrops and cores. Preliminary identification of tsunami deposits is often based on the recognition of anomalous layers of sand in environments where the deposition of sand layers is unusual, such as coastal marshes or lakes (Reinhart and Bourgeois, 1987). Tsunamis can transport sand, cobbles, boulders and debris from offshore and from beaches and deposit it over coastal lowlands (Dawson, 1994). However, other energetic processes, such as river flooding or storm surges, may leave sandy deposits in otherwise low-energy environments (Nelson et al., 1996). Key sedimentary characteristics of the deposit are often cited to confirm a tsunami origin for the sand layer. While no single characteristic may universally be used to distinguish a tsunami deposit, the combination of several characteristics are often used to rule out other processes and leave little or no doubt as to a tsunami origin for the deposit.

Tsunami deposits may be distinguished from river deposits by distinct biological markers, spatial distribution, sediment characteristics and geochemistry. The presence of marine or brackish water macro- and microfossils is used to infer a marine rather than river source for the deposit (Hemphill-Haley, 1995). Thinning and fining of the deposit landward are often used to suggest a marine surge rather than a river source for the deposit (Atwater, 1987; Benson et al., 1997). Flop-overs, which consist of the leaves and stems of herbaceous plants bent over by the flow, preserve information about flow direction and may indicate a landward-directed flow, suggesting a marine source (Atwater and Hemphill-Haley, 1997). The composition and texture of the sand grains has been used to differentiate between a coastal or upriver source (Darienzo and Peterson, 1990; Peterson and Darienzo, 1996). Geochemical indicators, such as bromine enrichment, have also been used to indicate a marine source for the deposit (Schlichting, 2000).

Storm surge deposits are more difficult to distinguish from tsunami deposits because, similar to tsunami deposits, they also contain marine or brackish water macro- and microfossils, have saltwater chemistry, and thin and fine landward (Nelson et al., 1996). Some studies use distance inland to indicate a tsunami source, arguing that it is not likely that storm waves or a storm surge could deposit sand inland to the extent of the deposit (Clague et al., 2000). Reinhart (1991) argues that in protected tidal channels, storms are unlikely to suspend the volume of sediment necessary to produce the deposits observed. When layers are present, their number and thickness are sometimes used to differentiate between a tsunami and storm deposit (Williams and Hutchinson, 2000, Witter, in press). Tsunami deposits tend to have several relatively thick normally graded beds, suggesting deposition from suspension by successive waves in the tsunami wave train, while storm deposits may be expected to have thinner and more numerous 
laminations from higher frequency but lower energy storm waves (Nelson et al., 1996b). Abramson (1998) uses the presence of rip-up clasts in the deposit to indicate the higher energy deposition of a tsunami.

Association of the sand layer with paleoseismicity is often used to link a sand layer to a tsunami source. Coseismic coastal subsidence may accompany great subduction zone earthquakes (Atwater, 1996). Association of the sand layer with evidence of coseismic subsidence is often key to the identification of the sand layer as a tsunami deposit (Atwater, 1987, Darienzo and Peterson, 1990). This is usually seen as a buried soil or layer of peat, representing a marsh surface that formed above the reach of high tide, abruptly overlain by a layer of sand (the tsunami deposit), which is then overlain by tidal flat mud. Linking a sand layer to liquifaction features also may tie a potential tsunami deposit to a seismic event (Atwater, 1992). The presence of stems of herbaceous plants in growth position within the deposit is used to indicate approximate coincidence of deposition of the sand layer with submergence of the marsh surface (Atwater, 1992).

Deposit geometry and the number of sand layers present in a core or outcrop are sometimes used to differentiate between a deposit produced by a tsunami from a great earthquake on the CSZ and one left by a tsunami with a distant source. Carver et al. (1996) proposed using deposit extent and thickness to differentiate CSZ tsunamis from distant tsunamis by comparing them to deposits left by historic distant tsunamis. Witter (2001) uses the estimated 500-540 year average recurrence interval for great CSZ earthquakes (Atwater and Hemphill Haley, 1997) to suggest that at least two out of four sand layers in a 600 year interval were deposited by distant tsunamis or storm surges. In lake deposits, the source of the tsunami (local or distant) may not be evident in the sediments (Clague, 1997).

\section{Scope of the database}

It is the goal of the authors that the database be comprehensive. The database currently cites 53 papers documenting 60 sites where known or potential tsunami deposits have been reported along the Cascadia margin (Figure 2). All known journal articles pertaining to specific sites along the Cascadia margin and published in English by the time of submission have been included. While every attempt has been made to include all theses and conference or symposium abstracts and proceedings that pertain to Cascadia tsunami deposits, the limited availability and inadequate referencing of some of these publications has made some omissions likely. Also, some conference abstracts that were superceded by journal publications were omitted if they did not contain any additional information. Similarly, if a USGS open file report was superceded by a USGS professional paper, only the professional paper was included.

The Cascadia Tsunami Deposit Database documents the variety found in tsunami deposits along the Pacific Northwest coast. It contains data on the age, number of deposits, sedimentary characteristics and identifying features of Cascadia tsunami deposits. It includes data from Northern California, north of the Mendocino triple junction through Vancouver Island, 
British Columbia, Canada. While the focus of the database are deposits from tsunamis that originate from earthquakes on the CSZ, data from historical tsunami deposits originating from trans-oceanic tsunamis are included for comparison. Tsunami deposits located in the Puget Sound area that are not believed to be of a Cascadia origin are not included in the database.

\section{Limitations of database}

Care should be exercised in using this data. No attempt has been made to verify the data presented in this report. The data derive from a wide variety of studies with differences in focus, scope, and intent. Details concerning techniques, errors, difficulties, inconsistencies, variability, and potential alternate interpretations of the data are beyond the scope of this report. These are usually site-specific and the original citation should be consulted. This report contains data from both peer-reviewed journals and from publications not typically subjected to extensive peer review. Techniques varied widely among the various studies and the accuracy and precision between separate entries may not be comparable. No attempt has been made in this report to quantify errors. The exception is in dating the deposits, where the errors reported in the publications are included. Even these may not be comparable due to differences in material dated, sampling techniques, or in the case of ages reported in calendar years, the calibration curve used and the error estimation method (Stuvier and Becker, 1986, 1993). It is recommended that the original reference, supplied for each entry, be consulted before using data compiled in this report.

\section{Categories used in the database}

The database uses the Microsoft Excel spreadsheet program to present the data and is also available in text format (tab delimited) and as an ArcView coverage. (Some entries may be truncated in ArcView at 255 characters. Please refer to text or Excel formats for complete entries.) Data categories are located on the horizontal axis (columns) and the site locations on the vertical axis (rows). Initially, the sites are sorted by latitude, from north to south, although data may be sorted by any data category in Excel by the user. The format of the data often varies from publication to publication. Wherever possible, we have used the authors own words or descriptions. Where conversions are clear and simple, we converted data into standard formats appropriate for the category, such as decimal degrees for latitude and longitude or centimeters for deposit thickness.

When a publication describes more than one tsunami deposit at a site, each deposit is catalogued separately (i.e. a separate row is used for each deposit). If significant differences in deposit characteristics are reported at different locations within a site, these are also catalogued separately. If an author uses one description to characterize several layers, these may be grouped into a single entry.

None of the publications cited in the database cover all data categories. Many are limited in scope and cover only a few categories. In others, tsunami deposits were only a secondary 
theme of the paper. For some sites, there is only mention that a tsunami deposit was present, but no details are given.

The data categories used in the database are:

location -The name of the location where the tsunami deposits are located, including state. The name may refer to the nearest easily recognized place name, such as a town, a body of water, or other geographic feature.

catalog \# - The catalogue number is an arbitrary number associated with each row entry. It may be used to refer to the entry or access the entry at a later date.

site \# - The site number is assigned in an ascending order based on latitude. The northernmost site in the database is assigned the number 1 and site number increases as the latitude of the site decreases. The site number of the southernmost site gives the total number of sites in the database.

core/section/secondary location - Where individual cores at a site are listed separately, the core number is given here. If no core number is given in the publication, a number is assigned. If the author divides a site into sections or secondary locations, their designations are given here. If no designation is given, one is assigned.

latitude and longitude - Latitudes and Longitudes reported by the authors are used when possible, otherwise they are measured from large-scale maps. Latitude and longitude are reported in decimal degrees.

depositional setting - Depositional setting for tsunami sedimentation, such as lake, coastal marsh, freshwater marsh, etc.

inundation distance, physiographic setting, and inundation reference - Inundation distance for open coastal settings is the maximum distance inland, normal to the shoreline, inundated by the tsunami. However, in other physiographic settings, the term inundation distance is subject to interpretation and the definition may change depending on the focus of the study. In a large bay or estuary, which may extend several kilometers inland from the open coast, a tsunami may propagate up a bay or even be focused by the bay. A tsunami that has a relatively small inundation distance in an open coastal setting or along a cliffed coast may travel several kilometers up a river or estuary. An inundation distance of $3 \mathrm{~km}$ when the site is located on a marshy riverbank does not suggest that the tsunami would inundate $3 \mathrm{~km}$ inland on the open coast. Therefore, when considering inundation distance, it is important to note the physiographic setting and the reference point from which inundation distance is measured. 
When known, the reference point for measuring the inundation distance is given (inundation reference)."Open coast" means the inundation distance is measured normal to the trend of the shoreline. This usually applies to lakes and back-barrier marshes in open coastal settings. When warranted, a more specific reference may be given. "River mouth" means the distance is measured from the mouth of the river or estuary, perpendicular to the trend of the coast at the river mouth. "Up river" means the distance up a river or estuary and will not necessarily be in a strait line but will follow the coarse of the river. Bayshore means perpendicular to the trend of the shore within a bay. When "bayshore" is added to river descriptions it means the distance is measured from the mouth of a river that flows into a bay. Fjords are treated like open coastal settings unless specifically referred to as a river or estuary. When a more specific term is required for clarification or if the inundation reference is not clear from the authors description, the authors words may be added or substituted for the above descriptions.

For a paleotsunami, the maximum inundation distances reported in the literature usually represent a minimum estimate. The reports are minimum estimates because the full extent of deposits may not be preserved in the geologic record and workable outcrop or coring sites may not extend the full length of the deposit. There is additional uncertainty in determining inundation distances for paleotsunami deposits because the locations of paleoshorelines are rarely known. The study of modern tsunami deposits suggests that actual inundation by a tsunami may extend a short distance beyond the limit of deposition and that deposits may be discontinuous near the limit of inundation (Nishimura and Miyaji, 1995).

elevation(mamsl) - the present elevation of a site, in meters above present mean sea level. For a paleotsunami site, both the elevation of the site and mean sea level at the time of the tsunami may have been different than at present.

barrier elevation (mamsl) - the elevation of a barrier a tsunami must have crossed to leave a deposit at the site, in meters above mean sea level. As with elevation above, we report the modern elevation.

observation/sampling method - method used in collecting data, such as observation from an outcrop or core, and, for cores, the type of coring device used (if specified in the citation).

\# cores/sampling localities - The number of cores or sampling localities at a site.

\# events documented (tsunami + subsidence) - The number of subsidence events associated with great earthquakes on the CSZ, whether or not they are associated with tsunamis. Tsunamis not associated with coseismic subsidence are also included. The number of coseismic events present at a site is an important tool to help correlate tsunami deposits. 
\# tsunami events documented at site - the number of tsunami events documented at a site. subsidence present? (y/n) - Are the tsunami deposits associated with coseismic subsidence?

\# subsidence events documented at site - the number of Subsidence events associated with great earthquakes on the CSZ documented at a site.

\# of tsunami deposits associated with subsidence - the number of tsunami deposits at a site that are associated with coseismic subsidence.

\# of tsunami deposits not associated with subsidence - the number of tsunami deposits at a site that are not associated with coseismic subsidence.

event \# - number assigned to event at a site (tsunami or subsidence), from youngest to oldest. Numbers are site - specific and do not imply correlation with events having the same number at a different site.

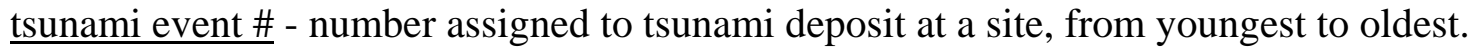

subsidence event \# - the number assigned to subsidence event at a site, from youngest to oldest.

amount of subsidence (m) - the amount of coseismic subsidence reported.

$\underline{\text { age }(\mathrm{rcybp})}$ - age of deposit in radiocarbon years before present. Ages reported are those of the authors and are usually reported relative to 1950. Ages reported in rcybp need to be calibrated before they can accurately represent the age of the deposit (see below).

age range (cybp) - The range of possible ages in calendar years before present. Following the convention of Stuvier and Pearson $(1986,1993)$, present is taken to be AD1950. Age ranges reported are those of the authors, though for consistency, we have converted ages reported as a date or relative to a date other than 1950 (such as 2000) to years before 1950. Age ranges in calendar years are calibrated using tree ring dendrochronology and take into account errors reported by the lab, errors in the calibration curve, reproducibility, etc. (Stuvier and Pearson, 1986; 1993).

correlated date - If the deposit is correlated by the author to a known or accepted event (such as the 1964 Alaska earthquake and tsunami or the 1700 Cascadia event), the correlated date is given here. 
age method/comments - Method used to determine the age of the deposits. The age reported represents a maximum age for the deposits. Material dated is usually organic material within the deposit or from the underlying peat layer and may include material that was dead prior to the tsunami or reworked material. Material in growth position or fragile material within the tsunami deposit often provides the most accurate dates. If a series of dates are given from material within or underlying the deposit, the youngest date is reported. Unless noted otherwise, dates reported here use conventional radiocarbon methods $\left(\mathrm{CO}_{2}\right.$ gas proportional counting, liquid scintillation). Dates calculated using accelerator mass spectrometry (AMS) are noted. Additional notes concerning the age or dating of the deposit is included here.

thickness (cm) - The reported thickness of the tsunami deposit, inclusive of all layers present. Thickness is not constant in tsunami deposits. Thinning of the deposit landward and away from channels often characterizes tsunami deposits. Different authors report thickness in different ways. Sometimes thickness is reported as an average thickness or representative thickness, other times only a local thickness is reported. Other times a range of thicknesses is reported.

maximum thickness (cm) - If a maximum thickness is reported independent of the average, representative, or range of thicknesses, it is reported here.

geometry - description of gradients in thickness (landward thinning, etc.) and continuity of the deposit.

\# layers - tsunami deposits often have distinct layering in them. Layers may be defined by sandmud couplets, heavy mineral layers, organic horizons, etc. The number of layers within a tsunami deposit is reported here.

layer thickness $(\mathrm{cm})$ - the thickness of individual layers is reported here.

layer characteristics - specific characteristics of individual layers, such as defining characteristics, texture, grading, etc. are reported here.

underlying material, overlying material - description of the material underlying and overlying the deposit.

lower contact, upper contact - description of the contacts bounding the tsunami deposit. Contacts are often characterized as either abrupt $(<0.1 \mathrm{~cm})$, sharp $(0.1 \mathrm{~cm}-0.5 \mathrm{~cm})$, or gradual $(>0.5 \mathrm{~cm})$, but some authors use other terms, such as mantled, erosive, irregular, gradational, etc. More detail is given when provided in the reference. 
grain size range - The size range of sand grains found in the deposit in units of phi $(\phi)$, where $\phi=$ $-\log _{2}$ of the grain diameter (in millimeters) (Krumbein, 1938). This usually is a typical range for the deposit. The presence of clay, silt or gravel may not be reflected in this statistic. The grain size range stated in the database is taken directly from the reference whenever possible. In the literature, grain size range is often given in units other than phi. When grain size range is given in millimeters or using standard terminology from the Udden-Wentworth grain-size scale (Udden, 1914, Wentworth, 1922), grain size range is interpreted using the following conversions:

very coarse sand $=1.000-2.000 \mathrm{~mm}=0.0--1.0 \mathrm{phi}$

coarse sand $=0.500-1.000 \mathrm{~mm}=1.0-0.0 \mathrm{phi}$

medium sand $=0.250-0.500 \mathrm{~mm}=2.0-1.0 \mathrm{phi}$

fine sand $=0.125-0.250 \mathrm{~mm}=3.0-2.0 \mathrm{phi}$

very fine sand $=0.062-0.125 \mathrm{~mm}=4.0-3.0 \mathrm{phi}$

grain size distribution - The distribution of grain sizes within a deposit

grain size description - Prose description of grain size within a deposit. The authors original words are given here whenever possible.

horizontal textural gradient - describes grain size changes in the horizontal direction, such as landward fining or fining away from the channel.

grading - grading describes textural changes in the vertical direction within a layer. Normal grading refers to fining upwards. Inverse grading refers to coarsening upwards.

sorting - sorting is a measure of the variability of the grain sizes in the deposit and is usually characterized from well sorted (little variability) to poorly sorted (large variability) (Folk, 1980). More quantitative statistical measures have not generally been reported in the Cascadia tsunami deposit literature.

other sedimentary structures or properties - miscellaneous sedimentary properties that characterize the deposit or grains within the deposit. The authors original words are given here whenever possible. 
composition - describes the mineralogical composition of the sediment grains in the deposit. Composition may be reported as specific minerals, percentages or presence of quartz, feldspar, and lithics (QFL), or other more general descriptions provided by the authors. Composition may provide clues to the source of the grains in the deposit.

inclusions - material other than sediment grains in a deposit, including plant material, shells or other macrofossils, artifacts, etc.

flow direction - gives the direction of flow indicated by the deposit. Flow direction indicators within the deposit may give either general (landward/seaward) or specific directions. Flow direction indicators include sedimentary structures and oriented inclusions such as flopovers (rooted plant material bent over by the tsunami).

microfossils - Microfossils, including forams and diatoms, may provide evidence for an ocean or coastal source for sediments in the deposit and therefore are a useful tool for identifying tsunami deposits. Microfossils may also provide evidence for the amount of coseismic subsidence that occurred during a subduction zone earthquake.

chemical evidence - describes any chemical evidence that the deposit is from a tsunami.

comments/additional descriptions - other information pertaining to the tsunami deposits, site, or publication that does not fit into the other categories is reported here.

reference - citing for reference that provided the data by author and year. Complete citing is listed in the reference section of this report and on the references worksheet in the database.

reference type - references are categorized as (1) journal: an article published for the scientific community in a major journal. Journal articles are usually subject to peer review and usually provide the most dependable data. (2) abstract: a short non- or minimally reviewed article usually prepared for a conference. Abstracts often present preliminary conclusions, give little detail, and, do to the lack of rigorous review, generally provide less dependable data. (3) often more detailed than an abstract and published in a conference proceedings volume, may or may not be subject to peer review. (4) theses: - Theses are scientific works completed by a M.S. or $\mathrm{Ph} . \mathrm{D}$. student as part of their degree. (5) USGS professional papers: detailed and peer-reviewed papers published by the U.S Geological Survey. When these supercede a USGS open-file report, the open file report is not included in the database.

reference date - date of reference publication 
map - reference map covering location of site. USGS 7.5 minute quadrangles are used for locations in the United States. National Topographic System (NTS) 1:50,000 maps published by Energy, Mines and Resources, Canada are used for locations in Canada.

\section{Acknowledgements}

We would like to thank all of the researchers whose work contributed data to the database. Their efforts made the Cascadia Tsunami Deposit Database possible. Reviews by Brian Atwater, Harvey Kelsey, and Roberto Anima greatly improved the database and report.

\section{References}

The references section includes the references cited in the text of this report and those cited in the database.

Abramson, H.F., 1998, Evidence for tsunamis and earthquakes during the last 3500 years from Lagoon Creek, a coastal freshwater marsh, northern California: M.S. thesis, Humboldt State University, $76 \mathrm{p}$.

Adams, J., 1990, Paleoseismicity of the Cascadia subduction zone: Evidence from turbidites off the Oregon-Washington margin: Tectonics, v. 9, n. 4, p. 569-583.

Atwater, B.F., 1992, Geologic evidence for earthquakes during the past 2000 years along the Copalis River, southern coastal Washington: Journal of Geophysical Research, v. 97, n. B2, p. 1901-1919.

Atwater, B., 1987, Evidence for great Holocene earthquakes along the outer coast of Washington state: Science, v.236, p.942-944.

Atwater, B., 1996, Coastal evidence for great earthquakes in western Washington: in Assessing earthquake hazards and reducing risk in the Pacific Northwest: Rogers, A. M., Walsh, T. J., Kockelman, W. J., and Priest, G. R., eds., U. S. Geological Survey Professional Paper 1560, p. 77-90.

Atwater, B. F., Cisternas, M.V., Bourgeois, J., Dudley, W.C., Hendley, J.W. II, Stauffer, P.H., 1999, Surviving a Tsunami - Lessons from Chile, Hawaii, and Japan: U. S. Geological Survey Circular 1187, 18 p. 
Atwater, B., and Hemphil-Haley, E., 1997, Recurrence intervals for great earthquakes of the past 3500 years at northeastern Willapa Bay, Washington: U.S. Geological Survey Professional Paper 1576, 108 p.

Atwater, B.F., Nelson, A.R., Clague, J.J., Carver, G.A., Yamaguchi, D.K., Bobrowski, P.T., Bourgeois, J., Darienzo, M.E., Grant, W.C., Hemphill-Haley, E., Kelsey, H.M., Jacoby, G.C., Nishenko, S.P., Palmer, S.P., Peterson, C.D., and Reinhart, M.A., 1995, Summary of coastal geologic evidence for past great earthquakes at the Cascadia subduction zone: Earthquake Spectra, v. 11, n. 1, p. 1-18.

Benson, B. E., Grimm, K. A., and Clague, J. J., 1997, Tsunami deposits beneath tidal marshes on northwestern Vancouver Island, British Columbia: Quaternary Research, v. 48, p. 192-204.

Briggs G.G., 1994, Coastal crossing of the elastic strain zero isobase, Cascadia margin, south central Oregon coast: Masters thesis, Portland State University, 251 p.

Briggs, G.G. and Peterson, C.D., 1992, Neotectonics of the south-central Oregon coast as recorded by late Holocene paleosubsidence of marsh systems: Geological Society of America Abstracts with Programs, v. 24, n. 5, p. 9-10.

Bobrowski, P.T. and Clague, J.J., 1995, Tsunami deposits beneath tidal marshes on Vancouver Island, British Columbia, Canada: in Tsunami deposits: Geologic warnings of future inundation: University of Washington, May 22-23, 1995, p.12.

Carver, G.A., Peterson, C.D., Garrison, C.E., and Koehler, R., 1996, Paleotsunami evidence of subduction earthquakes from northern California: Geological Society of America Abstracts with Programs, v. 28, n. 5, p.55.

Clague, J.J., 1995, Early historical and ethnographical accounts of large earthquakes and tsunamis on western Vancouver Island, British Columbia: Current Research 1195-A; Geological Survey of Canada, p. 47-50.

Clague, J.J., Bobrowski, P.T., and Hamilton, T.S.,1994, A sand sheet deposited by tsunami at Port Alberni, British Columbia: Estuarine, Coastal, and Shelf Science, v. 38, p. 413-421.

Clague, J.J., Bobrowski, P.T., and Hutchinson, I., 2000, A review of Geological records of large tsunamis at Vancouver Island, British Columbia, and implications for hazard: Quaternary Science Reviews, v.19, p. 849-863. 
Clague, J.J., Hutchinson, I., Mathews, R.W., and Patterson, R.T., 1999, Evidence for late Holocene tsunamis at Catala Lake, British Columbia: Journal of Coastal Research, v. 15, n. 1, p.45-60.

Clague, J.J. and Bobrowski, P.T., 1994 (a), Tsunami deposits beneath tidal marshes on Vancouver Island, British Columbia: Geological Society of America Bulletin, v. 106, p. 1293-1303.

Clague, J.J. and Bobrowski, P.T., 1994 (b), Evidence for a large earthquake and tsunami 100400 years ago on western Vancouver Island, British Columbia: Quaternary Research, v. 41, p. 176-184.

Darienzo, M.E., 1991, Late Holocene paleoseismicity along the northern Oregon coast: Ph.D. dissertation, Portland State University, 167 p.

Darienzo, M.E. and Peterson, C.D., 1990, Episodic tectonic subsidence of late Holocene salt marshes, northern Oregon central Cascadia margin: Tectonics, v. 9, n. 1, p. 1-22.

Darienzo, M.E., and Peterson, C.D., 1995, Magnitude and frequency of subduction zone earthquakes along the northern Oregon coast in the past 3,000 years: Oregon Geology, v. 57, n. 1, p. 3-12.

Darienzo, M.E., Peterson, C.D., and Clough, C., 1994, Stratigraphic evidence for great subduction-zone earthquakes at four estuaries in northern Oregon: Journal of Coastal Research, v. 10, n. 4, p. 850-876.

Dawson, A. G., 1994, Geomorphological effect of tsunami run-up and backwash: Geomorphology, v. 10, p. 83-94.

Folk, R.L., 1980, The Petrology of Sedimentary Rocks: Hemphill Publishing Company, Austin, Texas, $184 \mathrm{p}$.

Garrison, C.E., Abramson, H.F., and Carver, G.A, 1997, Evidence for repeated tsunami inundation from two freshwater coastal marshes, Del Norte County, California: Geological Society of America Abstracts with Programs, v. 29, n. 5, p. 15.

Grant, W.C. and McLaren, D.D., 1987, Evidence for Holocene subduction earthquakes along the northern Oregon coast: EOS (Transactions, American Geophysical Union), v. 68, p. 1239. 
Heaton. T.H. and Kanimori, H., 1984, Seismic potential associated with subduction in the Northwestern United States: Bulletin of the Seismological Society of America, v. 74, n. 3, p. 933-941.

Heaton, T. H. and Snavely, P. D., 1985, Possible tsunami along the northwestern coast of the United States inferred from Indian traditions: Bulletin of the Seismological Society of America, v. 75, n. 5, p. 1455-1460.

Hutchinson, I., Clague, J.C., and Mathewes, R.W., 1995, A tsunami record from Kanim Lake, central west coast of Vancouver Island: in Tsunami Deposits: Geologic Warnings of Future Inundation, University of Washington, May 22-23, 1995, p .23.

Hutchinson, I., Clague, J.C., and Mathewes, R.W., 1997, Reconstructing the tsunami record on an emerging coast: a case study of Kanim Lake, Vancouver Island, British Columbia: Canada; Journal of Coastal Research, v.13, n. 2, p. 545-553.

Hutchinson, I., Guilbault, J.-P., Clague, J.J., and Bobrowsky, P.T., 2000, Tsunamis and tectonic deformation at the northern Cascadia margin: a 3000 year record from Deserted Lake, Vancouver Island, British Columbia, Canada: The Holocene, v.10, n.4, p. 429-439.

Kelsey, H.M., Witter, R.C., and Polenz, M., 1993: Cascadia paleoseismic record derived from late Holocene fluvial and lake sediments, Sixes River valley, Cape Blanco, south coastal Oregon: EOS (Transactions, American Geophysical Union), v. 74, p. 199.

Kelsey, H.M., Witter, R. C., and Nelson, A.R., 1994, Repeated abrupt late Holocene environmental changes in south coastal Oregon: Stratigraphic evidence at Sixes river Marsh and Bradley Lake: Geological Society of America Abstracts with Programs, v. 26, n. 5, p. 524.

Kelsey, H. M., Nelson, A.R., and Hemphill-Haley, E., 1995, Properties and depositional characteristics of tsunamis in south coastal Oregon from a paired coastal-lake and marsh study: in Tsunami Deposits: Geologic Warnings of Future inundation, University of Washington, p. 20.

Kelsey, H. M., Nelson, A.R., Hemphill-Haley, E. and Witter, R. C., 1998a, Short-term and long term changes in ocean level recorded by a coastal freshwater meromitic lake, Cascadia subduction zone, southern Oregon: Geological Society of America Abstracts with Programs, v. 30, n. 7, p. 162 . 
Kelsey, H. M., Witter, R. C., and Hemphill-Haley, E., 1998b, Response of a small Oregon estuary to coseismic subsidence and postseismic uplift in the past 300 years: Geology, v. 26, n. 3, p. 231-234.

Kelsey, H. M., Witter, R. C. and Hemphill-Haley, E., 2002, Plate-boundary earthquakes and tsunamis of the past 5,500 yr, Sixes River estuary, southern Oregon, Geological Society of America Bulletin, v. 114, p. 298-314.

Krumbein, W.C., 1938, Size -frequency distributions of sediments and the normal phi curve: Journal of Sedimentary Petrology, v.8, p. 84-90.

Leroy, T. H., 1999, Holocene sand dune stratigraphy and paleoseismicity of the north and south spits of Humboldt Bay, Northern California: Masters thesis, Humboldt State University, 50 p.

Li, W., 1992, Evidence for the late Holocene coseismic subsidence in the lower Eel River Valley, Humboldt county, northern California: An application of foraminiferal zonation to indicate tectonic submergence: Masters thesis, Humboldt State University, 80 p.

Lopez, G.I. and Bobrowski, P.T., 2001, A 14,000 year old record from a coastal freshwater lake: Sedimentological evidence for tsunamigenic events on the west coast of Vancouver Island, British Columbia, Canada: Proceedings of the International Tsunami Symposium 2001, Seattle, Washington, August 7-10, 2001, p. 493-502.

Minor, R. and Grant, W. C., Earthquake-induced subsidence and burial of late Holocene archaeological sites, northern Oregon coast: American Antiquity, v. 61, n. 4, p. 772-782.

Nelson, A.R. and Peronius, S.F., 1996, Great earthquake potential in Oregon and Washington an overview of recent coastal geologic studies and their bearing on segmentation of Holocene ruptures, central Cascadia Subduction zone: in Assessing Earthquake Hazards and Reducing Risk in the Pacific Northwest, Rogers, A. M., Walsh, T. J., Kockelman, W. J., and Priest, G. R., eds., USGS Professional Paper 1560, p. 91-114.

Nelson, A.R., Kelsey, H.M., Hemphil-Haley, E., Witter, R.C., 1998a, AMS 14C dating of a 7300-year earthquake history from an Oregon coastal lake: Geological Society of America Abstracts with Programs, v. 30, n. 7, p. 162.

Nelson, A.R., Ota, Y., Umitsu, M., Kashima, K., and Yoshiaki, M., 1998b, Seismic or hydrodynamic control of rapid late-Holocene sea-level rises in southern coastal Oregon, USA? The Holocene, v. 8, n. 3, p. 287-299. 
Nelson, A.R., Shennan, I., and Long, A.L., 1996, Identifying coseismic subsidence in tidal wetland stratigraphic sequences at the Cascadia subduction zone of western North America: Journal of Geophysical Research, v. 101, n. B3, p. 6115-6135.

Peterson, C. D. and Darienzo, M. E., 1988, Field trip guide for Netarts Bay, Oregon: Oregon Geology, v. 50, n. 9/10, p. 99-106.

Peterson, C. D. and Darienzo, M. E., 1996, Discrimination of climatic, oceanic, and tectonic mechanisms of cyclic marsh burial: in Assessing Earthquake Hazards and Reducing Risk in the Pacific Northwest, Rogers, A. M., Walsh, T. J., Kockelman, W. J., and Priest, G. R., eds., USGS Professional Paper 1560, p. 115-146.

Peterson, C. D., Darienzo, M. E., Burns, S. F., and Burris, W. K, 1993; Field trip guide to Cascadia paleoseismic evidence along the northern Oregon coast: evidence of subduction zone seismicity in the central Cascadia margin: Oregon Geology, v. 55, n. 5, p. 99-114.

Peterson, C.D. and Priest, G.R.,1995, Preliminary reconnaissance survey of Cascadia paleotsunami deposits in Yaquina Bay, Oregon: Oregon Geology, v.57, n. 2, p. 33-40.

Reinhart, M.A. , 1991, Sedimentological analysis of postulated tsunami-generated deposits from Cascadia great-subduction earthquakes along southern coastal Washington: Unpublished M.S. project, University of Washington Department of Geological Sciences, 83 p.

Reinhart and Bourgeois, 1987, Distribution of anomalous sand at Willapa Bay, Washington: Evidence for Large-scale landward-directed processes: EOS (Transactions, American Geophysical Union), v. 68, n. 44, p. 1469.

Schlichting, R.B, 2000, Establishing the inundation distance and overtopping height of paleotsunami from the late-Holocene geologic record at open coastal wetland sites, central Cascadia margin: Masters Thesis, Portland State University, 166 p.

Schlichting, Peterson, C., and Qualman, D., 1999, Establishing long inundation distances of prehistoric tsunami from siliciclastic and bio-geochemical tracers in open-coast, beach plain wetlands, central Cascadia margin, USA: EOS (Transactions, American Geophysical Union), v. 80, n. 46. p. 520-521.

Stuvier, M. and Becker, B. (1993) High precision decadal calibration of the radiocarbon time scale, AD 1950-6000 BC: Radiocarbon, v. 35, n. 1, p. 35-65. 
Stuvier, M. and Becker, B. (1986): High precision decadal calibration of the radiocarbon time scale, AD 1950-2500 BC: Radiocarbon, v. 28, n. 2B, p. 863-910.

Shennan, I, Long, A.J. , Rutherford, M.M., Innes, J.B., Green, F.M., and Walker, K.J., 1998, Tidal marsh stratigraphy, sea-level change and large earthquakes -II: Submergence events during the last 3500 years at Netarts Bay, Oregon, USA: Quaternary Science Reviews, v. 17, p. 365-393.

Shennan, I., Long, A.J., Rutherford, M.M., Green, F.M., Innes, J.B., Lloyd, J.M., Zong, Y. and Walker, K.J., 1996, Tidal marsh stratigraphy, sea-level change and large earthquakes - I: A 5000 year record in Washington, U.S.A.: Quaternary Science Reviews, v.15, p. 1023-1059.

Udden, J.A., 1914, Mechanical composition of clastic sediments: Geological Society of America Bulletin, v. 25, p. 655-644.

Walsh, T.J., Caruthers, C.G., Heinitz, A.C., Meyers, E.P. III, Baptista, A.M., Erdakos, G.B., and Kamphaus, R.A., 2000, Tsunami hazard map of the southern Washington coast: Modeled Tsunami Inundation from a Cascadia Subduction Zone Earthquake: Washington Division of Geology and Earth Resources, Geologic Map GM-49.

Wentworth, C.K., 1922, A scale of grade and class terms for clastic sediments: Journal of Geology, v. 30, p. 377-392.

Williams, H.F.L., 1995, Stratigraphic and foraminiferal evidence for earthquake-induced subsidence and attending tsunami about 300 years ago at Sooke Inlet, southern Vancouver Island, Canada: in Tsunami Deposits: Geologic Warnings of Future inundation, University of Washington, p.13.

Williams, H. and Hutchinson, I., 2000, Stratigraphic and microfossil evidence for late Holocene Tsunamis at Swantown Marsh, Whidbey Island, Washington: Quaternary Research, v. 54, p. 218-227.

Williams, H., Hutchinson, I., and Nelson, A., 2002, Multiple sources for late Holocene tsunamis at Discovery Bay, Washington State. EOS (Transactions, American Geophysical Union), v. 83 , n. 47.

Witter, R.C. and Kelsey, H.M., 1994, Abrupt late Holocene relative sea-level changes in three coastal marshes along the southern Oregon portion of the Cascadia Subduction Zone: EOS (Transactions, American Geophysical Union), v. 75, n. 44, p. 621-622. 
Witter, R. C., Kelsey, H. M. and Hemphill-Haley, E. 2001, Pacific storms, El Nino and Tsunamis, Competing mechanisms for sand deposition in a coastal marsh, Euchre Creek, Oregon, Journal of Coastal Research, 17, 563-583.

Witter, R. C., 1999, Late Holocene paleoseismicity, tsunamis, and relative sea-level changes along the south-central Cascadia subduction zone, southern Oregon, U.S.A. : Ph. D. dissertation, University of Oregon. $152 \mathrm{p}$.

Witter, R.C., and Kelsey, H.M., 1996, Repeated abrupt changes in the depositional environments of a freshwater marsh: a record of late Holocene paleoseismicity at Eucre Creek, south coastal Oregon: Geological Society of America Abstracts with Programs, v. 28, n. 5, p. 125. 


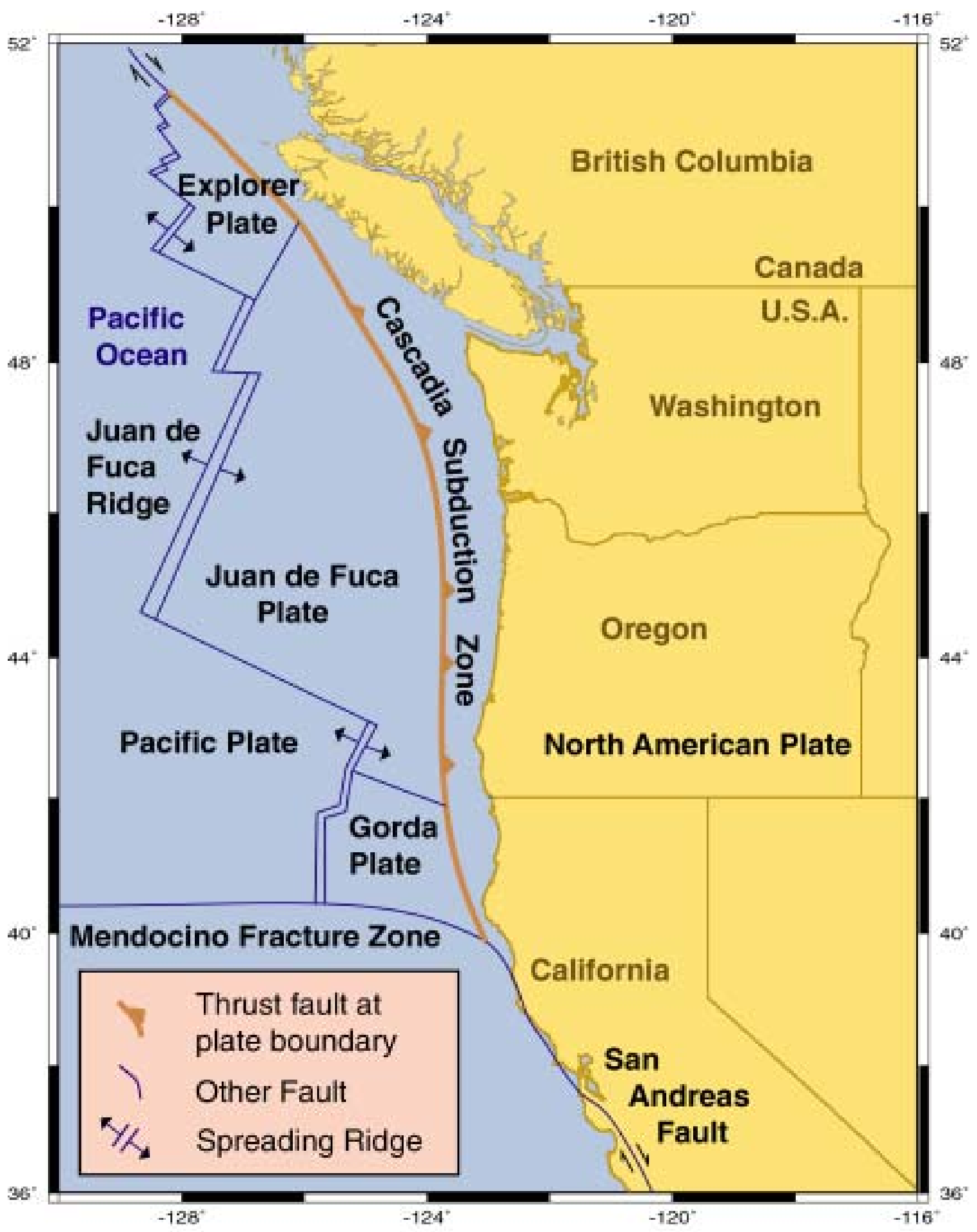

Figure 1 Map illustrating the main features of the tectonics of the Cascadia margin. 


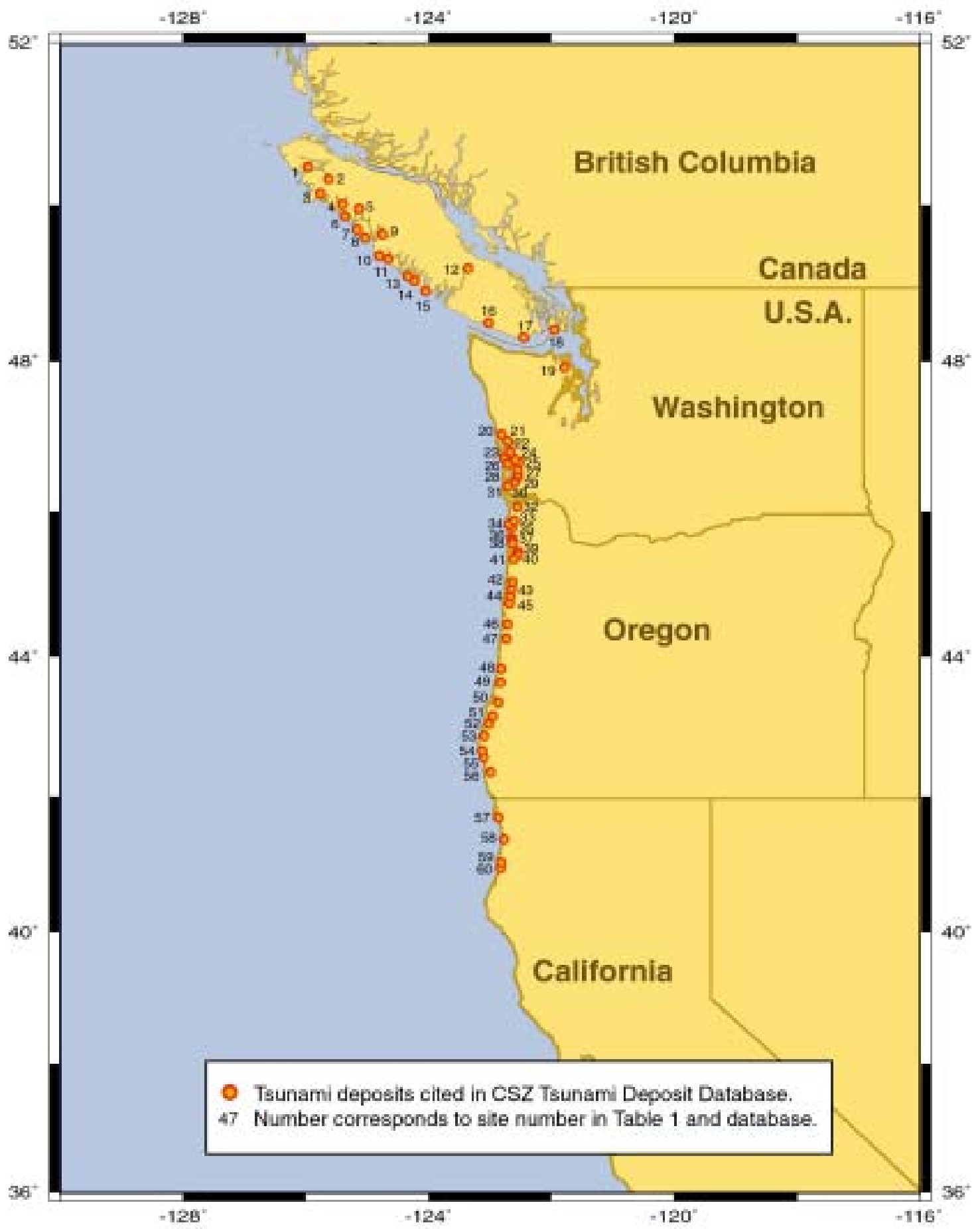

Figure 2 Map showing locations of tsunami deposits along the Cascadia margin. Numbers beside deposit markers correspond to site numbers in Table 1 and in the database. 
Table 1. Site number, name, and references for sites included in Cascadia Tsunami Deposit Database. Site Number corresponds to numbers in Figure 2 and to catalog numbers in database.

\begin{tabular}{|c|c|c|}
\hline \# & Site & Reference \\
\hline 1 & Koprino Harbour, Vancouver Island, B.C. & Benson et al., 1997 \\
\hline 2 & Neroutsos Inlet, Vancouver Island, B.C. & Benson et al., 1997 \\
\hline 3 & Power Lake, Vancouver Island, B.C. & Clague et al., 2000 \\
\hline 4 & Fair Harbour, Vancouver Island, B.C. & Benson et al., 1997 \\
\hline 5 & Zeballos, Vancouver Island, B.C. & $\begin{array}{l}\text { Bobrowski and Clague, 1995; Clague et al., } \\
2000\end{array}$ \\
\hline 6 & Catala Lake, B.C. & Clague et al., 1999 \\
\hline 7 & Deserted Lake, B.C. & Clague et al., 2000; Hutchinson et al., 2000 \\
\hline 8 & Louie Bay, Vancouver Island, B.C & $\begin{array}{l}\text { Clague et al., 2000; Lopez and Bobrowski, } \\
2001\end{array}$ \\
\hline 9 & Channel Lagoon, Vancouver Island, B.C & $\begin{array}{l}\text { Clague et al., 2000; Lopez and Bobrowski, } \\
2001\end{array}$ \\
\hline 10 & Kanim Lake, Vancouver Island, B.C. & Clague et al., 2000; Hutchinson et al., 1997 \\
\hline 11 & Hot Springs Cove, Vancouver Island, B.C. & Lopez and Bobrowski, 2001 \\
\hline 12 & Port Alberni, Vancouver Island, B.C. & $\begin{array}{l}\text { Clague and Bobrowski, 1994a; Clague et al. } \\
1994\end{array}$ \\
\hline 13 & Kakawis Lake, B.C. & $\begin{array}{l}\text { Clague et al., 2000; Lopez and Bobrowski, } \\
2001\end{array}$ \\
\hline 14 & Tofino, Vancouver Island, B.C. & Clague and Bobrowski, 1994a \\
\hline 15 & Ucluelet, Vancouver Island, B.C. & Clague and Bobrowski, 1994a \\
\hline 16 & Port Renfrew, Vancouver Island, B.C. & Clague et al., 2000 \\
\hline 17 & Sooke Inlet, Vancouver Island, B.C. & Williams, 1995 \\
\hline 18 & Swantown Marsh, Whidbey Island, WA & Williams and Hutchinson, 2000 \\
\hline 19 & Discovery Bay, WA & Williams et al., 2002 \\
\hline 20 & Copalis River, WA & Atwater, 1992; Reinhart, 1991 \\
\hline 21 & North Bay, Grays Harbor, WA & Reinhart, 1991 \\
\hline 22 & Johns River, Grays Harbor, WA & Reinhart, 1991; Shennan et al., 1996 \\
\hline 23 & Grayland Plains, WA & Schlichting, 2000; Schlichting et al. 1999 \\
\hline 24 & North River, Willipa Bay, WA & $\begin{array}{l}\text { Reinhart, 1991; Reinhart and Bourgeois, } \\
1987\end{array}$ \\
\hline 25 & Smith River, Willipa Bay, WA & Reinhart, 1991 \\
\hline 26 & Cedar River, Willipa Bay, WA & Reinhart and Bourgeois, 1987 \\
\hline 27 & Bone River, Willipa Bay, WA & $\begin{array}{l}\text { Reinhart, 1991; Reinhart and Bourgeois, } \\
1987\end{array}$ \\
\hline 28 & Niawiakum River, Willipa Bay, WA & $\begin{array}{l}\text { Atwater, 1987, 1996; } \\
\text { Atwater and Hemphil-Haley, 1997; } \\
\text { Hemphil-Haley, 1995; Reinhart, 1991; } \\
\text { Reinhart and Bourgeois, } 1987\end{array}$ \\
\hline 29 & Palix River, Willipa Bay, WA & $\begin{array}{l}\text { Reinhart, 1991; Reinhart and Bourgeois, } \\
1987\end{array}$ \\
\hline 30 & Nemah River, Willipa Bay, WA & Reinhart and Bourgeois, 1987 \\
\hline 31 & Long Beach Peninsula, WA & Schlichting, 2000; Schlichting et al. 1999 \\
\hline
\end{tabular}


Table 1 (continued)

\begin{tabular}{|c|c|c|}
\hline \# & Site & Reference \\
\hline 32 & Youngs Bay, Columbia River, OR & Peterson et al., 1993 \\
\hline 33 & Stanley Lake, OR & Darienzo et al., 1994; Peterson et al., 1993 \\
\hline 34 & Necanicum River, OR & Darienzo et al., 1994 \\
\hline 35 & Neawanna Creek, OR & $\begin{array}{l}\text { Darienzo , 1991; Darienzo and Peterson, } 1995 \text {; } \\
\text { Darienzo et al., 1994; Peterson et al., } 1993\end{array}$ \\
\hline 36 & Ecola Creek, OR & $\begin{array}{l}\text { Darienzo and Peterson, } 1995 \text {; Peterson et al., } \\
1993\end{array}$ \\
\hline 37 & Cannon Beach, OR & Schlichting et al. 1999 \\
\hline 38 & Rockaway, OR & Schlichting, 2000; Schlichting et al. 1999 \\
\hline 39 & Oyster Farm, Netarts Bay, OR & Darienzo. 1991 \\
\hline 40 & Wee Willies, Netarts Bay, OR & Darienzo. 1991; Peterson et al., 1993 \\
\hline 41 & Netarts Marsh, OR & $\begin{array}{l}\text { Darienzo. 1991; Darienzo and Peterson, 1990, } \\
\text { 1995; Peterson and Darienzo, 1988; Peterson et } \\
\text { al., 1993; Shennan et al., 1998 }\end{array}$ \\
\hline 42 & Nestucca Bay, OR & $\begin{array}{l}\text { Darienzo. 1991; Darienzo and Peterson, 1994, } \\
\text { 1995; Peterson et al., } 1993\end{array}$ \\
\hline 43 & Neskowin, OR & Schlichting, 2000; Schlichting et al. 1999 \\
\hline 44 & Salmon River, OR & $\begin{array}{l}\text { Atwater et al., 1999; Grant and McLaren, 1987; } \\
\text { Minor and Grant, } 1996\end{array}$ \\
\hline 45 & Silitz Bay, OR & $\begin{array}{l}\text { Darienzo. 1991; Darienzo and Peterson, 1995; } \\
\text { Darienzo et al., 1994; Peterson et al., } 1993\end{array}$ \\
\hline 46 & Yaquina, OR & $\begin{array}{l}\text { Darienzo. 1991; Darienzo and Peterson, 1995; } \\
\text { Darienzo et al., } 1994\end{array}$ \\
\hline 47 & Alsea Bay, OR & $\begin{array}{l}\text { Darienzo. 1991; Darienzo and Peterson, 1995; } \\
\text { Peterson and Darienzo, } 1996\end{array}$ \\
\hline 48 & Lily lake, OR & Briggs and Peterson, 1992 \\
\hline 49 & Suislaw Bay, OR & Briggs, 1994 \\
\hline 50 & Umpqua River, OR & Briggs, 1994 \\
\hline 51 & Coos Bay, OR & $\begin{array}{l}\text { Briggs, 1994; Nelson and Peronius, 1996, } \\
\text { Nelson et al, 1998b }\end{array}$ \\
\hline 52 & Coquille River, OR & Witter, 1999 \\
\hline 53 & Bradley Lake, OR & $\begin{array}{l}\text { Kelsey et al., 1994, 1995, 1998a; } \\
\text { Nelson et al., 1998a }\end{array}$ \\
\hline 54 & Sixes River Estuary, OR & $\begin{array}{l}\text { Kelsey et al., 1993, 1994, 1995, 1998b; Witter } \\
\text { and Kelsey, } 1994\end{array}$ \\
\hline 55 & Elk River, OR & Witter and Kelsey, 1994 \\
\hline 56 & Eucre Creek, OR & $\begin{array}{l}\text { Witter and Kelsey, 1994, 1996; } \\
\text { Witter et al., } 2002\end{array}$ \\
\hline 57 & Crescent City, CA & Carver et al., 1996; Garrison et al., 1997 \\
\hline 58 & Lagoon Creek, CA & Abramson, 1998; Garrison et al., 1997 \\
\hline 59 & South Humboldt Spit, CA & Leroy, 1999 \\
\hline 60 & Eel River, CA & $\mathrm{Li}, 1992$ \\
\hline
\end{tabular}

